TITLE:

\title{
ANATOMICAL AND MECHANICAL CHARACTERISTICS OF LEAF- SHEATH FIBROVASCULAR BUNDLES IN PALMS
}

$\operatorname{AUTHOR}(S)$ :

Zhai, Shengcheng; Imai, Tomoya; Horikawa, Yoshiki; Sugiyama, Junji

\section{CITATION:}

Zhai, Shengcheng ... [et al]. ANATOMICAL AND MECHANICAL CHARACTERISTICS OF LEAFSHEATH FIBROVASCULAR BUNDLES IN PALMS. IAWA Journal 2013, 34(3): 285-300

\section{ISSUE DATE:}

2013

URL:

http://hdl.handle.net/2433/180656

\section{RIGHT:}

(C) International Association of Wood Anatomists, 2013 Published by Koninklijke Brill NV, Leiden; This is not the published version. Please cite only the published version.; この論文 は出版社版でありません。引用の際には出版社版をご確認ご利用ください。 


\title{
Morphological and mechanical characteristics of fiber bundles in palm species
}

\author{
Shengcheng Zhai ${ }^{1}{ }^{*}$, Yoshiki Horikawa ${ }^{1}$, Tomoya Imai ${ }^{1}$, Junji Sugiyama ${ }^{1}$
}

\section{Abstract}

This study presents morphological characteristics, mechanical properties, microfibril angles (MFAs) and

Klason lignin contents of fiber bundles from 18 palm species. Observed by light microscopy, all fiber

bundles consisted equally of thick-walled sclerenchyma fibers $\left(\mathrm{S}_{\mathrm{F}}\right)$ and vascular tissue $\left(\mathrm{S}_{\mathrm{V}}\right)$, while the shape and localization of vascular tissues on the transverse sections varied among species. It was possible to group these fiber bundles into 3 types: type I - rounded in the central region; type II - angular in the marginal region; and type III - aliform in the central region. These 3 morphological types of fiber bundles were closely correlated with current phylogenetic classification of palm species. This research confirmed the correlation between diameter and mechanical properties of palm fiber bundles; tensile strength and Young's modulus showed a decreasing trend with increasing diameter. We clarified that this trend was due to a marked increase in the proportion of transverse sectional area comprised by vascular tissue with increasing diameter of fiber bundles. The MFAs of fiber bundles ranged from $10.3^{\circ}$ to $47.1^{\circ}$, which were generally larger than those of non-woody plants, conifers, and broad-leaved trees. The Klason lignin contents of palm species were also high, ranging from $18.3 \%$ to $37.8 \%$, with a mean value of $29.6 \%$. These large MFAs and high lignin contents could lead to the long-term plastic deformation and relatively low

1 Research Institute for Sustainable Humanosphere, Kyoto University, Uji, Kyoto 611-0011, Japan *Corresponding author

E-mail: zhai sc@rish.kyoto-u.ac.jp 
tensile strength of palm fiber bundles.

\section{Keywords}

Arecaceae; fiber; vascular tissue; tensile strength; MFAs; Klason lignin

\section{Introduction}

The palm family (Arecaceae) consists of approximately 210 genera and 2800 species. Most palm species are distributed in tropical and subtropical areas, particularly in tropical Asia and America, with some species in Africa (Tomlinson 1961, 1990; Tomlinson et al. 2011; Pei et al. 1991). Some of the species have been cultivated as economically important agricultural products. Numerous palm species have been described in the literature, including coconut palm (Cocos nucifera), oil palm (Elaeis guineensis), nipa palm (Nypa fruticans), and others (Law et al. 2007; Munawar et al. 2007; Khalil et al. 2008; Tamunaidu \& Saka 2011; Shinoj et al. 2011). However, many other common palm species are distributed throughout Asia and America, and play important roles in local areas. For instance, windmill palm (Trachycarpus fortunei) growing in Asia areas provides a rich source of fiber bundles and is known for its use in thatched roofs, sofas, mats, mattresses, marine ropes, and traditional working tools (Zhai et al. 2012; 2013). The Kitul palm (Caryota urens), growing in humid tropical Asia, is commonly cultivated in villages and is best known for the production of jaggery (a crude brown sugar) in Sri Lanka. The Kitul palm provides a significant source of income for local economies (Ratnayake et al. 1990; de Zoysa 1992; Ashton et al. 1998). Furthermore, the Corypha palms provide raw material for palm-leaf manuscripts. Large collections of palm-leaf manuscripts are available in archives, museums, libraries, and Buddhist Gompas in India and 
Southeast Asia (Swarnakamal 1965; Dhawan 1995; Anupam 2002).

The widespread use of palms by humans has received much attention. The palm family is known to have been important to past civilizations; palm remains are often excavated at archaeological sites

(Morcote-Ríos \& Bernal 2001; Li 2008). Today, some palm species also provide important biomass resources, and large amounts of palm biomass are produced in various locations. Physical characterization of palm biomass may facilitate the use of currently unexploited raw materials for fuels and chemicals.

However, few publications have reported on the morphological and mechanical characteristics of palm fiber bundles. In order to fulfill requirements for modern commercial utilization of palms, fundamental studies, such as the characterization of the basic properties of palm fiber bundles, are required. This paper presents the morphological characteristics, mechanical properties, microfibril angles (MFAs), and Klason lignin contents of fiber bundles of 18 palm species, and discusses the correlation between diameter and mechanical properties common to palm species. These studies can facilitate further utilization of this widespread natural fiber resource.

\section{Materials and methods}

\subsection{Materials}

In general, after the soft ground tissues of leaf-sheath breakdown, it leaves a reticulate mass of fiber bundles covering around the whole palm trunk (Tomlinson 1961, 1990). The remained fiber bundles are easily hand-collected from palm stem surface. Eighteen species belonging to 14 palm genera produced fiber bundles from leaf-sheath and were selected for the study: Arenga engleri, Arenga sp., Butia capitata, 
Caryota maxima, Caryota monostachya, Caryota urens, Cocos nucifera, Corypha umbraculifera, Elaeis

guineensis, Livistona chinensis, Medemia nobilis, Phoenix dactylifera, Phoenix roebelenii, Rhapis excelsa,

Sabal umbraculifera, Syagrus romanzoffiana, Trachycarpus fortunei, and Washingtonia filifera. The fiber

bundles of these species were collected from the surfaces of palm trees at Beijing Botanical Garden,

Kunming Botanical Garden, Shenzhen Botanical Garden, Nanjing Botanical Garden, and Taipei Botanical

Garden in China. The fiber bundles were rinsed in running tap water to remove dust from their surface.

These samples were air dried prior to use in further experiments.

\subsection{Morphological observation of fiber bundles}

At least 10 fiber bundles of each palm species were embedded in Epoxy resin. Transverse sections

(3- $\mu \mathrm{m}$ thick) were cut from the embedded specimens using a semi-thin microtome (Leica RM2145,

Germany) with a glass knife, and stained by safranin to observe lignified tissue. The sectional images were created using a light microscope (Olympus BX51, Japan) equipped with a digital camera (Olympus DP73, Japan). These images were used for quantitative analysis of the morphological characteristics using standard shareware software ImageJ (v.1.46r, National Institutes of Health, USA). Morphological characteristics examined included (1) the component cell types of a fiber bundle, (2) the localization of sclerenchyma fibers and vascular tissue (xylem vessels and phloem tissues) in a fiber bundle, and (3) the amount of transverse sectional area occupied by sclerenchyma fibers $\left(\mathrm{S}_{\mathrm{F}}\right)$ and the area occupied by vascular tissue $\left(\mathrm{S}_{\mathrm{V}}\right)$ in a fiber bundle. The ratio of vascular tissue area to total transverse sectional area $\left(\mathrm{S}_{\mathrm{V}}\right.$ / $\mathrm{S}_{\mathrm{F}}+\mathrm{S}_{\mathrm{V}}$ ) was also calculated. 


\subsection{Measurement of fiber dimensions and derived values}

The dimensions of fibers include length, diameter, cell-wall thickness, and lumen diameter. Thirty fiber bundles from each palm species were macerated at $60^{\circ} \mathrm{C}$ for $24 \mathrm{~h}$ in a solution of acetic acid and hydrogen peroxide (1:1 ratio) (Franklin 1954). After maceration, all specimens were washed with distilled water for neutralization, and were shaken gently in the distilled water until individual fibers were separated from the fiber bundles. The fibers were then stained with $1 \%$ safranin solution to observe the lignified tissue. The dimensions of 30 fibers were measured, and average values with standard deviations were calculated for each palm species. An ANOVA was performed to test for significant differences $(P<0.05)$ in fiber dimensions among palm species.

Three derived values were also calculated using fiber dimensions:

1. Slenderness ratio $=$ Fiber length/Fiber diameter

2. Flexibility coefficient $=($ Fiber lumen diameter/Fiber diameter $) \times 100 \%$

3. Runkel ratio $=($ Fiber cell-wall thickness/Fiber lumen diameter $) \times 2$

The fiber dimensions and derived values were compared with published data to assess the suitability of the palms for pulping and other utilizations.

\subsection{X-ray diffraction analysis}

Typical fiber bundles were taken from the 18 palm species for X-ray diffraction analysis. The X-ray diffraction diagrams were obtained using a Bruker Hi-Star detector using $\mathrm{CuK} \alpha$ radiation (= $1.5418 \AA$ ) produced by a rotating anode X-ray generator at tube voltage $45 \mathrm{kV}$ and tube current $90 \mathrm{~mA}$ (MAC 
Science M18XHF). The distance between the specimen and the detector was $15 \mathrm{~cm}$. The data were

processed, merged, and scaled using the SAINT program (Bruker) (Watanabe et al. 2002). All

measurements were performed in triplicate. The files were converted into 16-bit image files by FIT2D

(European Synchrotron Radiation Facility, France). Using image analysis software ImageJ (v.1.46r), the

MFA was determined based on azimuthal intensity distribution of 200 reflections of cellulose $\mathrm{I}_{\beta}$ (Hori \&

Wada 2005; Zhai et al. 2012).

\subsection{Measurement of Klason lignin contents}

The Klason lignin (acid-insoluble lignin) contents of palm fiber bundles were determined using the

TAPPI standard T-222 (1998). The palm fiber bundles were extracted using sulfuric acid (72\% w/w) as a reagent, and the residue was used to determine Klason lignin. The fiber bundles were not pretreated with ethanol-benzene, because of limited amounts of sample. All measurements were performed in triplicate. It has been suggested that the ash content of acid-insoluble residue should be measured to obtain accurate results for Klason lignin (Sluiter et al. 2011). The residues were transferred to crucibles and placed in a muffle furnace at $575 \pm 2^{\circ} \mathrm{C}$ for $5 \mathrm{~h}$ to obtain ash content.

\subsection{Tensile strength test of fiber bundles}

All fiber bundles were air-dried to a moisture content ranging from $8 \%$ to $10 \%$ by weight. After cutting the fiber bundles into 20-25 mm lengths, the bundles were fixed on paper frames with 10-mm gauge length (Zhai et al. 2012) by medium-viscosity epoxy adhesives (Aron Alpha EX2020, Toagosei America, Inc., Japan), according to the preparation procedure mentioned in the ASTM D 3379-75 standard (1978). 
The diameter of each fiber bundle was measured using a digital optical microscope (Micro Square,

DS-3USV, RAS Machine Tool Technologies, Inc., USA) at 10 randomly selected points. The transverse sectional area of each fiber bundle was determined using the circle equation based on the mean value of measured diameter.

Prior to mechanical testing, specimens were conditioned at $60 \%$ relative humidity and $20^{\circ} \mathrm{C}$ for $1 \mathrm{mo}$.

Following the ASTM D-882 standard, the mechanical properties of fiber bundles were determined using a universal testing machine (Instron 4411) with a crosshead speed of $1 \mathrm{~mm} / \mathrm{min}$. Before testing, the middle part of the supporting paper was cut. Thirty fiber bundles from each palm species were tested in order to perform statistical analyses. The data were assessed by ANOVA to test for significant differences $(P<$ $0.05)$.

\section{Results and Discussion}

\subsection{Morphological characteristics of palm fiber bundles}

The shape and localization of the vascular tissue on transverse sections of fiber bundles varied among the different palm species. A fiber bundle consists equally of thick-walled sclerenchyma fibers and vascular tissue (xylem vessels and phloem tissues). Figure 1 shows transverse-sectional images of the fiber bundles for each of the 18 palm species, taken with the same magnification. On the basis of the morphological differences in the vascular tissue, the palm fiber bundles were classified into 3 types I, II, and III as illustrated on the right side of Figure 2. Eight palm species had rounded vascular tissue located in the central region of the fiber bundles; these species were grouped into type I- vascular tissue rounded 
in the central region. The5 species in the genera Arenga and Caryota had rounded/angular vascular tissue located in the marginal region of a fiber bundle; these species were grouped into type II - vascular tissue angular in marginal region. In the remaining 5 species, the vascular tissue was aliform in the central region; these species were grouped into type III - vascular tissue aliform in the central region (Fig. 2). The 3 types of fiber bundles also showed close correlation with the phylogenetic classification of palm species (Fig. 2). The fiber bundles from the tribes Cocoseae, Borasseae, and Phoeniceae were classified as type I, and those from the tribe Caryoteae were classified as Type II. With the exception of $R$. excelsa, the fiber bundles from the tribes Trachycarpeae, Coryoheae, and Sabaleae were classified as type III. In general, the anatomical differences between different palm species within a genus are quantitative or so small as to be obscured by the variation exhibited by a single individual (Tomlinson 1961). The observations presented here provide the first account showing a close correlation between the current phylogenetic classification and the shape and localization of vascular tissues within different palm species. Considering the large number of palm species that occur worldwide, the morphology of vascular tissue of fiber bundles in other palms is worthy of investigation.

A remarkable feature of the 18 palm species examined here is that the ratio of vascular tissue area to entire transverse sectional area increased markedly with increasing diameter of fiber bundles. Figure 3 shows examples of this dynamic from 5 palm species. This morphological feature also has a strong correlation with the mechanical properties of fiber bundles, as will be described in section 3.3.

A specific feature observed in 3 species of Caryota and in P. dactylifera was that the safranin staining in 
sclerenchyma fibers was uneven, as indicated by the white and black dotted circles in Figure 1. This feature could be caused by differences in cell-wall thickness. Examining the data listed in Table 1, the standard deviation of cell-wall thickness in Caryota fibers was approximately $\pm 1 \mu \mathrm{m}$, suggesting that the difference in color staining of fiber bundles was affected by cell-wall thickness. The thin-walled fibers usually appeared at the central region of fiber bundles; the presence of thin-walled fibers may decrease the mechanical strength of the fiber bundles. Furthermore, the morphological characteristics of the sclerenchyma fibers from different palm fiber bundles were surveyed using a maceration method. The length, diameter, and cell-wall thickness of fibers from the 18 palm species are presented in Table 1. Fiber lengths varied from 0.66 to $1.85 \mathrm{~mm}$. Fibers in the genera Arenga and Caryota were longer than those of other palm species, with an average value of $1.57 \mathrm{~mm}$. The average fiber length of $P$. roebelenii and $T$. fortunei was $<0.7 \mathrm{~mm}$, much shorter than that of the other palm species. Table 1 also shows the derived values (pulp-quality indices) of fibers from different palm species. On the basis of the flexibility coefficient, fibers of conifer and broad-leaved trees are classified into 4 groups: 1 , highly elastic $(>75) ; 2$, elastic (50-75); 3, rigid (30-50); and 4, highly rigid (<30) (Bektas et al. 1999; Kiaei 2011). The flexibility coefficients in Arenga spp. and B. capitata were $<50$; these fibers can be considered as rigid. The flexibility coefficients the fibers from the other 15 palm species ranged between 50 and 75 ; these fibers are considered elastic.

\subsection{Microfibril angles and Klason lignin contents}

The MFAs of fiber bundles among the 18 palm species, as analyzed by X-ray diffraction, varied from 
$10.3^{\circ}$ to $47.1^{\circ}\left(\right.$ mean $\left.=25.4^{\circ}\right)($ Table 2$)$. The MFAs of palm fibers were larger than those reported for other non-woody plant fibers including flax $\left(11^{\circ}\right)$, jute $\left(8.1^{\circ}\right)$, sisal $\left(10-22^{\circ}\right)$, pine apple $\left(8-14^{\circ}\right)$, and banana $\left(11^{\circ}\right)$ (Satyanarayana et al. 1982; Baley 2002). The MFAs of palm species were also larger than those reported for wood fibers and tracheids (El-Osta et al. 1973; Yamamoto et al. 1993; Lichtenegger et al. 1999; Bonham \& Barnett 2001).

The Klason lignin contents of fiber bundles from the different palm species ranged from $18.38 \%$ to $37.8 \%$, with a mean value of $29.6 \%$ (Table 2). These values are much higher than those reported for other non-woody plants, including flax (2.0\%), jute (15.9\%), sisal (12\%), and banana (12\%) (Baley 2002; Razera \& Forllini 2003; Cordeiro et al. 2004; Megiatto et al. 2007). Lignin contents of the palm species were similar to those reported for conifers, including noble fir (Abies procera, 29.3\%), western white pine (Pinus monoticola, 19.3\%), and Douglas fir (Pseudotsuga menziesii, 27.2\%). Palm fiber bundles had relatively high lignin content compared to those reported for broad-leaved trees, including yellow birch (Betula alleghaniensis, 22.7\%), quaking aspen (Populus tremuloides, 19.3\%), and basswood (Tilia Americana, 20.0\%)(Panshin et al. 1964).

\subsection{Mechanical properties of palm fiber bundles}

Typical stress-strain (S-S) curves of fiber bundles among the palm species are shown in Figure 4. The

S-S curves varied among the species and showed a yield, followed by long-term plastic deformation until breakage from $8 \%$ to $62 \%$ strain. These data indicate that palm fiber bundles are strong and tough, i.e., they could show passive elongation before breakage, and the long-term plastic deformation allows them to 
dissipate energy. Table 2 shows the mechanical properties of fiber bundles of the various palm species. The tensile strengths of palm fiber bundles were lower than those of other non-woody plants, including flax (1339 MPa), jute (466 MPa), seagrass (573 MPa), sisal (568-640 MPa), and cotton (287-597 MPa)

(Satyanarayana et al. 1982; Baley 2002; Razera \& Forllini 2003; Davies et al. 2007; Müsig 2010), but were higher than those of pine (40 MPa) and rubberwood (15 MPa) (Munawar et al. 2007). Young's moduli of all palm fiber bundles were lower than those of flax ( $58 \mathrm{GPa})$, jute (26.5 GPa), seagrass (19.8 GPa), and oak (11 GPa) (Satyanarayana et al. 1982; Baley 2002; Davies et al. 2007; Munawar et al. 2007). In addition, the breakage strain of palm fiber bundles showed much higher values than those of non-woody plants, including flax (3.3\%), jute (8.1\%), seagrass (3.4\%), sisal (3-7\%), and banana (1.0-3.5\%)

(Satyanarayana et al. 1982; Baley 2002). The high lignin contents in combination with large MFAs account for the relatively low tensile strength, limited elastic deformation, and long-term plastic deformation of palm fiber bundles.

We found that the diameter of fiber bundles influenced the tensile strength and Young's modulus for all 18 palm species. The general relationships between diameter and mechanical properties of fiber bundles from 5 selected palm species are illustrated in Figure 5. It is striking that as diameter increased, tensile strength and Young's modulus decreased. A similar phenomenon was found in fiber bundles from flax (Baley 2002), ramie, abaca leaf, and pineapple leaf (Munawar et al. 2007). This phenomenon cannot be easily explained, because if the characteristics of fiber bundles are the same, the mechanical properties of fiber bundles of different diameters should also be the same. Our previous publication pointed out that the 
thick-walled sclerenchyma fibers predominantly contribute to the mechanical properties of fiber bundles in windmill palm, while vascular tissues tend to reduce mechanical strength (Zhai et al. 2012). Considering the similar structural and mechanical properties of the individual fiber cells in a fiber bundle, the ratio of vascular tissue to the entire transverse sectional area (sclerenchyma + vascular tissue) would be a key factor affecting mechanical properties of the fiber bundles in palm species. In the present research, we found that this ratio increased markedly with increasing diameter of fiber bundles (Fig. 3), indicating that the percentage of sclerenchyma fibers that affected mechanical properties decreased. These results demonstrated that the larger the diameter of fiber bundles, the lower the mechanical strength, in all of the palm species examined.

\section{Conclusions}

This study on the morphological characteristics and mechanical properties of fiber bundles from different palm species showed 3 distinct types of fiber bundles, based on the shape and localization of vascular tissues. These 3 types of fiber bundles showed a close correlation with the phylogenetic classification of palm species.

The correlation between diameter and mechanical properties of fiber bundles was clarified. By observing the area occupied by sclerenchyma fibers and vascular tissue, we found that the proportion of the transverse sectional area comprised by vascular tissue increased markedly with increasing diameter of palm fiber bundles. These findings explain why tensile strength and Young's modulus decreased with increasing diameter of fiber bundles. 
The large MFAs of palm fibers in combination with high lignin contents, result in limited elastic

deformation, long-term plastic deformation, and relatively low tensile strength of palm fiber bundles. This illustration of the correlation between the morphological characteristics and mechanical properties of palm fibers provides information that will be useful for decision making regarding palm utilization.

\section{References}

American Society for Testing and Materials, 1978. ASTM D 3379-75 standard test method for tensile strength and Young's modulus for high-modulus single-filament materials. pp.847--852. ASTM, Philadelphia.

Anupam, S. 2002. Palm leaf manuscripts of the world: material, technology and conservation. Studies in

Conservation. Suppl.1, 15--24. Maney Publishing.

Ashton, P.M.S., S. Gamage, I.A.U.N. Gunatilleke \& C.V.S. Gunatilleke. 1998. Using Caribbean pine to establish a mixed plantation: testing effects of pine canopy removal on plantings of rain forest tree species.

Forest Ecol. Manag. 106: 211--222.

Baley, C. 2002. Analysis of the flax fibres tensile behaviour and analysis of the tensile stiffness increase.

Compos. Part A. 33: 939--948.

Bektas, I., A. Tutus \& H. Eroglu. 1999. A study of the suitability of Calabrian pine (Pinus brutiaten) for pulp and paper manufacture. Turkish J. Agric. Forest. 23: 589--599.

Bonham, V.A. \& J.R. Barnett. 2001. Fibre length and microfibril angle in silver birch (Betula pendula Roth). Holzforschung. 55: 159--162. 
Cordeiro, N., M.N. Belgacem, I.C. Torres \& J.C.V.P. Moura. 2004. Chemical composition and pulping of banana pseudo-stems. Ind. Crop Prod. 19: 147--154.

Davies, P., C. Morvan, O. Sire \& C. Baley. 2007. Structure and properties of fibres from sea-grass (Zostera marina). J Mater. Sci. Vol. 42(13): 4850--4857.

de Zoysa, N.D. 1992. Tapping patterns of the Kitul palm (Caryota urens) in the Sinharaja area Sri Lanka.

Principes. 36(1): 28--33.

Dhawan, S. 1995. Essential oil for prevention of mould growth on palm leaf manuscripts. In: Proceeding of the Third International Conference on Biodeterioration of Cultural Property. The Conservation Science

Division, The Fine Arts Department, Bangkok, pp. 272--282.

Dransfield, J., N.W. Uhl, C.B. Asmussen, W.J. Baker, M.M. Harley \& C.E. Lewis. 2008. Genera Plamarum.

The evolution and classification of palms. Kew Publishing, Royal Botanic Gardens, Kew, UK.

El-Osta, M.L., R.M. Kellogg, R.O. Foschi \& R.G. Butters. 1973. A direct X-ray technique for measuring microfibril angle. Wood and Fiber. 5: 118--128.

Franklin, G.L. 1954. A rapid method for softening wood for anatomical analysis. Tropical woods. 88:

$35--36$.

Hori, R. \& M. Wada. 2005. The thermal expansion of wood cellulose crystals. Cellulose. 12: 479--484.

Khalil, H.P.S.A., M.N. Azura, A.M. Issam, M.R. Said \& T.O.M. Adawi. 2008. Oil palm empty fruit bunches (OPEFB) reinforced in new unsaturated polyester composites. J Reinf. Plast. Compos. 27(16-17): 1817--1826. 
Kiaei, M. 2011. Basic density and fiber biometry properties of hornbeam wood in three different altitudes at age 12. Middle-east J. Sci. Res. 8: 663--668.

Law, K.N., W.R.W. Daud \& A. Ghazali. 2007. Morphological and chemical nature of fiber stands of oil palm empty-fruit bunch (OPEFB). BioResources 2(3): 351--362.

Li, S. 2008. Bencao gangmu (1578) - compendium of materia medica. Science and Technology Publishing, Shanghai (in Chinese).

Lichtenegger, H., A. Retterer, S. Stanzl-Tschegg \& P. Fratzl. 1999. Variation of cellulose microfibril angles in softwoods and hardwoods - a possible strategy of mechanical optimization. J. Struct. Biol. 128: 257--269.

Megiatto, J., W. Hoareau, C. Gardrat, E. Frollini \& A. Castellan. 2007. Sisal fibers: Surface chemical modification using reagent obtained from a renewable source; characterization of hemicellulose and lignin as model study. J. Agric. Food Chem. 55: 8576--8584.

Morcote-Ríos, G. \& R. Bernal. 2001. Remains of palms (Palmae) at archaeological sites in the New World: A review. Bot. Rev. 67(3): 309--350.

Munawar, S.S., K. Umemura \& S. Kawai. 2007. Characterization of the morphological, physical, and mechanical properties of seven nonwood plant fiber bundles. J. Wood Sci. 53: 108--113.

Müsig, J. 2010. Industrial applications of natural fibers: Structure, properties and technical applications. John Wiley \& Sonsm Ltd. United Kingdom.

Panshin, A.J., C. de Zeeuw \& H.P. Brown. 1964. Textbook of wood technology. Volume I - Structure, 
identification, uses, and properties of the commercial woods of the United States (2nd edition).

McGraw-Hill, Inc. USA.

Pei, S., S. Chen \& S. Tong. 1991. Tomun13(1): Angiospermae-Monocotyledoneae, Palme, Flora of

Reipublicae Popularis Sinicae. Science Press, Beijing (in Chinese).

Ratnayake, P.D.K.C., C.V.S. Gunatilleke \& I.A.U.N. Gunatilleke. 1990. Caryota urens L. (Palmae): An indigenous multiple purpose tree species in the wet lowlands of Sri Lanka. Regional Workshop on

Multipurpose Tree Species, IFS/ Winrock Int., Los Banos, Philippines.

Razera, I.A.T. \& E. Forllini. 2003. Composites based on jute fibers and phenolic matrices: properties of

fibers and composites. J. Appl. Polymer Sci. 91(2): 1077--1085.

Satyanarayana K.G., C.K.S. Pillai, K. Sukumaran, S.G.K. Pillai, P.K. Rohatgi \& Kalyanivijayan. 1982.

Structure property studies of fibres from various parts of the coconut tree. J. Mater. Sci. 17: 2453--2462.

Shinoj, S., R. Visvanathan, S. Panigrahi \& M. Kochubabu. 2011. Oil palm fiber (OPF) and its composites:

A review. Ind. Crop. Prod. 33: 7--22.

Sluiter, A., B. Hames, R. Ruiz, C. Scarlata, J. Sluiter, D. Templeton \& D. Crocker. 2011. Determination of

Structural Carbohydrates and Lignin in Biomass. National Renewable Energy Laboratory, Golden, CO,

USA. http://www.nrel.gov/biomass/analytical_procedures.html.

Swarnakamal, B. 1965. Conservation of palm-leaf manuscripts. Baroda Museum and Picture Gallery, Bull.

19: 59--65.

Tamunaidu, P. \& S. Saka. 2011. Chemical characterization of various parts of nipa palm (Nypa fruticans). 
Ind. Crop. Prod. 34: 1423--1428.

TAPPI Standard T 222. 1998. Acid insoluble lignin in wood and pulp.

Tomlinson, P.B. 1961. Anatomy of the monocotyledons. II . PALMAE. Oxford University Press, London.

Tomlinson, P.B. 1990. The structural biology of palms. Clarendon Press, Oxford.

Tomlinson, P.B., J.W. Horn \& J.B. Fisher. 2011. The anatomy of palms. Oxford University press, New

York.

Watanabe, A., T. Yoshimura, B. Mikami, H. Hayashi, H. Kagamiyama \& N. Esaki. 2002. Reaction mechanism of alanine racemase from Bacillus stearothermophilus. J. Biol. Chem. 277(21): 19166--19172.

Yamamoto, H., T. Okuyama \& M. Yoshida. 1993. Method of determining the mean microfibril angle of wood over a wide range by the improved Cave's method. Mokuzai Gakkaishi. 39: 375--381.

Zhai, S., D. Li, B. Pan, J. Sugiyama \& T. Itoh. 2012. Tensile strength of windmill palm (Trachycarpus fortunei) fiber bundles and its structural impactions. J. Mater. Sci. 47: 949--959.

Zhai, S., Y. Horikawa, T. Imai \& J. Sugiyama. 2013. Cell wall characterization of windmill palm

(Trachycarpus fortunei) fibers and its functional implications. IAWA J. 34(1) in press. 

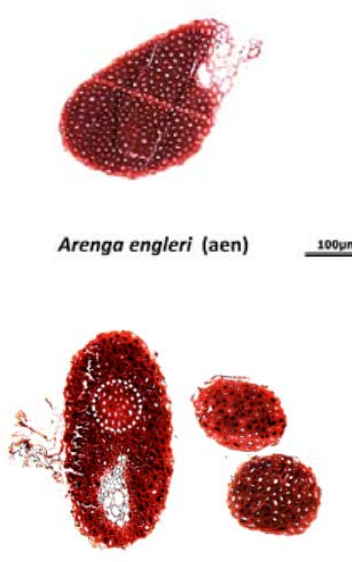

Caryota maxima (cma)

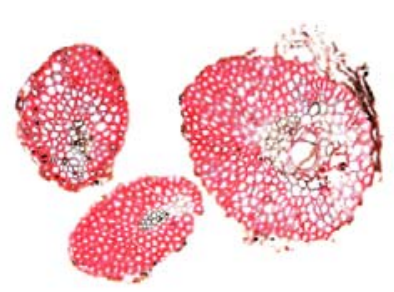

Cocos nucifera (cnu)
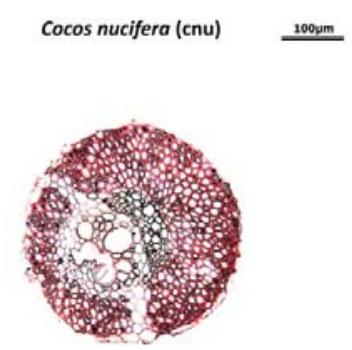

Livistona chinensis (lch)

$\underline{100 \mathrm{ym}}$
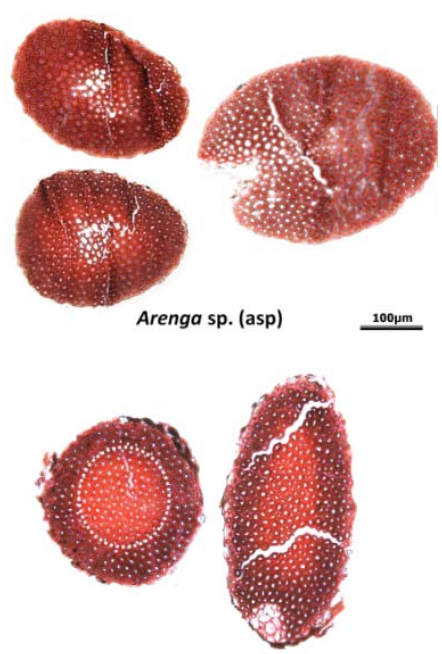

Caryota monostachya $(\mathrm{cmo})$
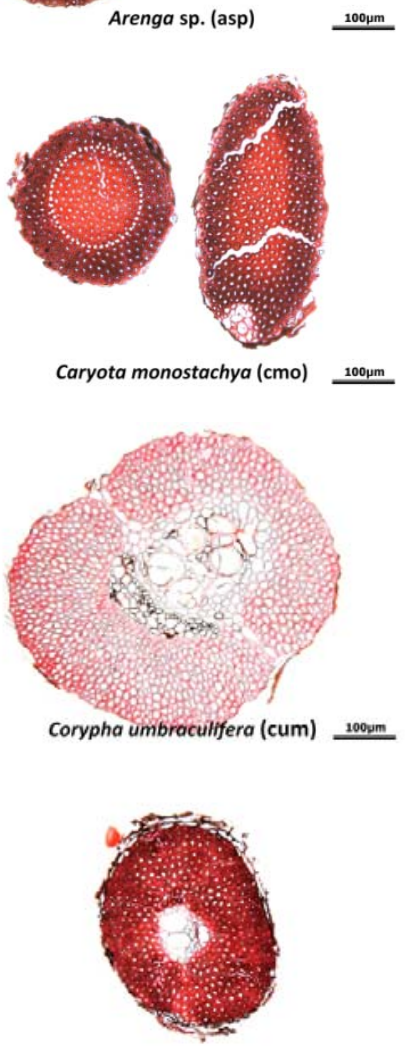

Medemia nobilis (mno)
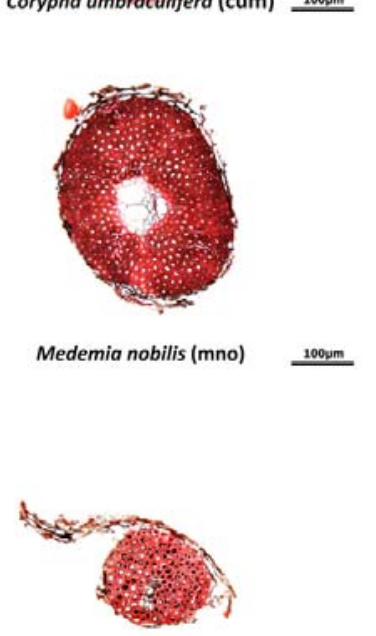

Rhapis excelsa (rex)
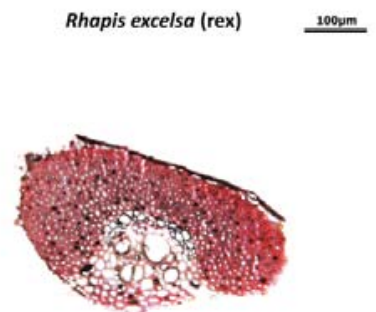

Trachycarpus fortunei (tfo)

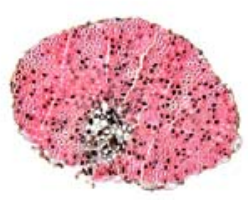

Butia capitata (bca) $\quad \underline{100 \mathrm{ym}}$
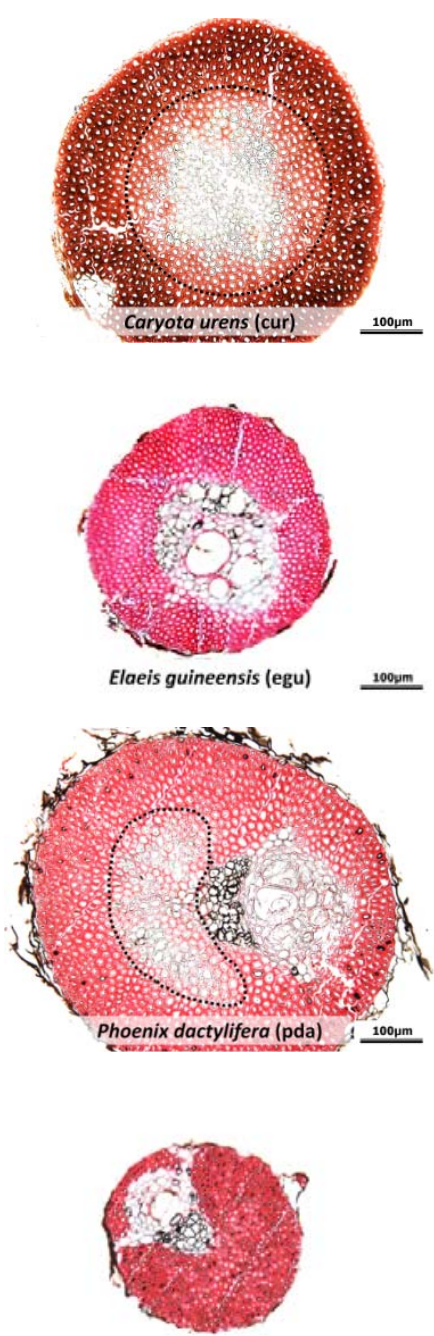

Sabal umbraculifera (sum)

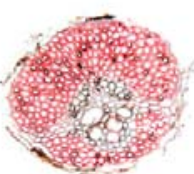

Washingtonia filifera (wfi) 100ym

Fig. 1. Transverse sectional images of fiber bundles among 18 palm species taken by light microscope with the same magnification. The dotted circles in Caryota maxima, Caryota monostachya, Cayota urens and Phoenix dactylifera, indicate the area of thin-walled fibers in fiber bundles. 


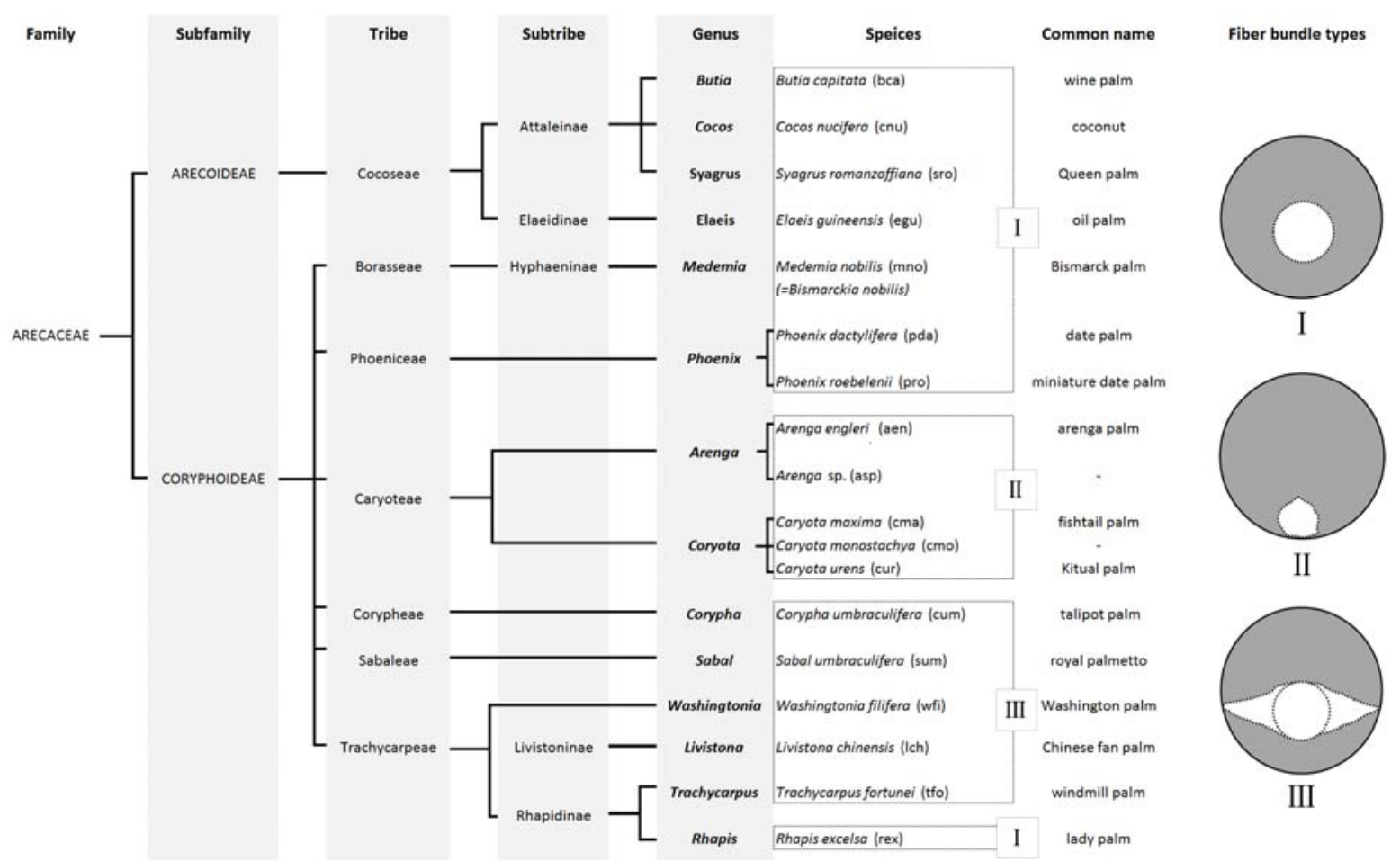

Fig. 2. A diagram to show the phylogenetic classification of 18 species in palm family (ARECACEAE), redrawn from Dransfield et al. (2008) and Tomlinson et al. (2011). I , II, III indicate three types of fiber bundles among 18 different palm species, where the gray area is occupied by sclerenchyma fibers and the white area by a vascular tissue.

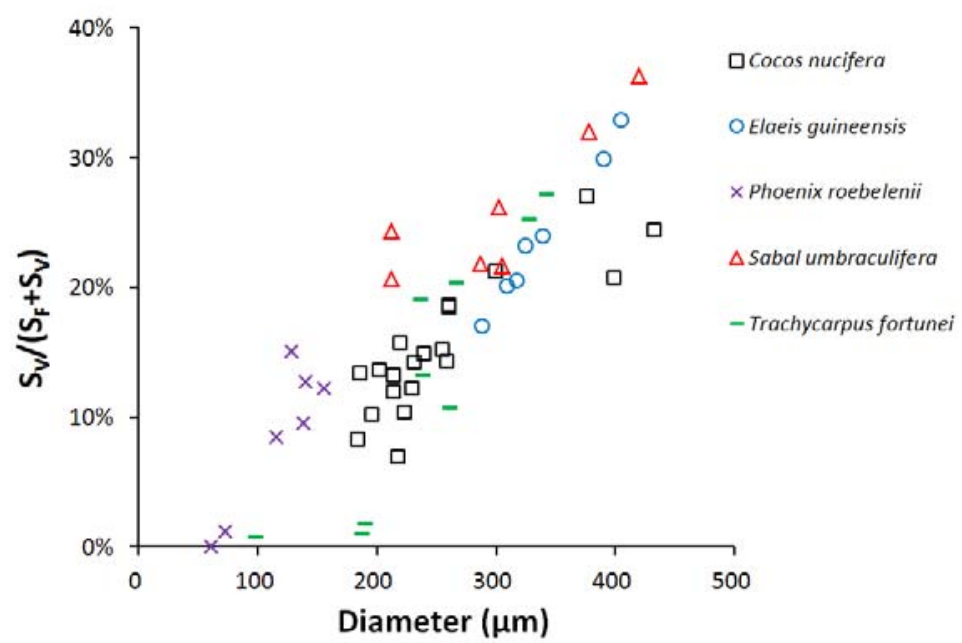

Fig. 3. The ratio of vascular tissue area to whole transverse sectional area $\left(=\mathrm{S}_{\mathrm{V}} / \mathrm{S}_{\mathrm{F}}+\mathrm{S}_{\mathrm{V}}\right)$ against diameter of fiber bundles from five palm species. 


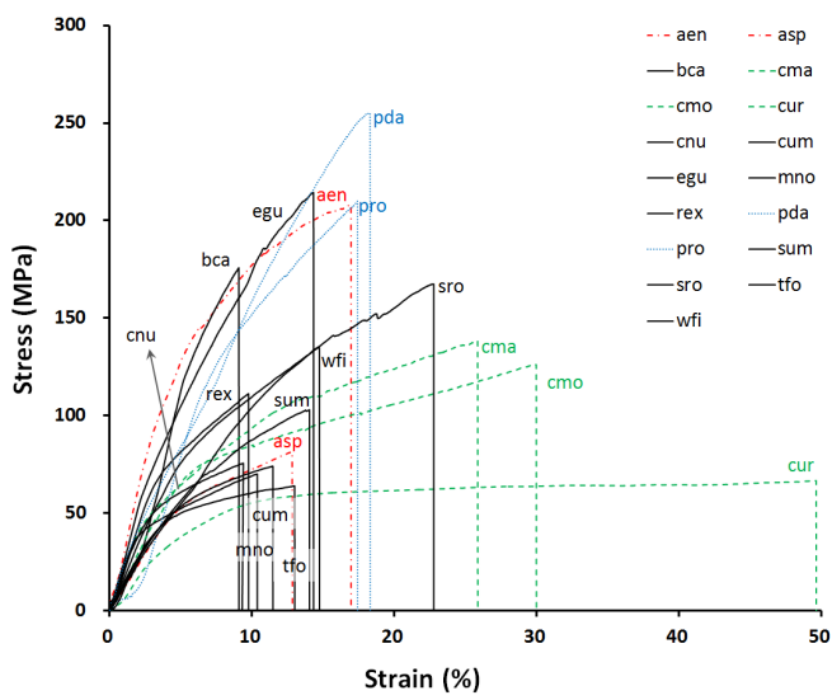

Fig. 4.Typical stress-strain curves of fiber bundles of different palm species, obtained at a crosshead speed of $1 \mathrm{~mm} \mathrm{~min}^{-1}$ and using a gauge length of 10mm. Dash-dot line, dash line and dot line show stress-strain curves of species from Arenga (aen , asp), Caryota (cma, cmo, cur) and Phoenix (pda, pro) genus, respectively. Other species are in solid line. The abbreviations presented in the figure legend of this figure refer to that of Figure 1.
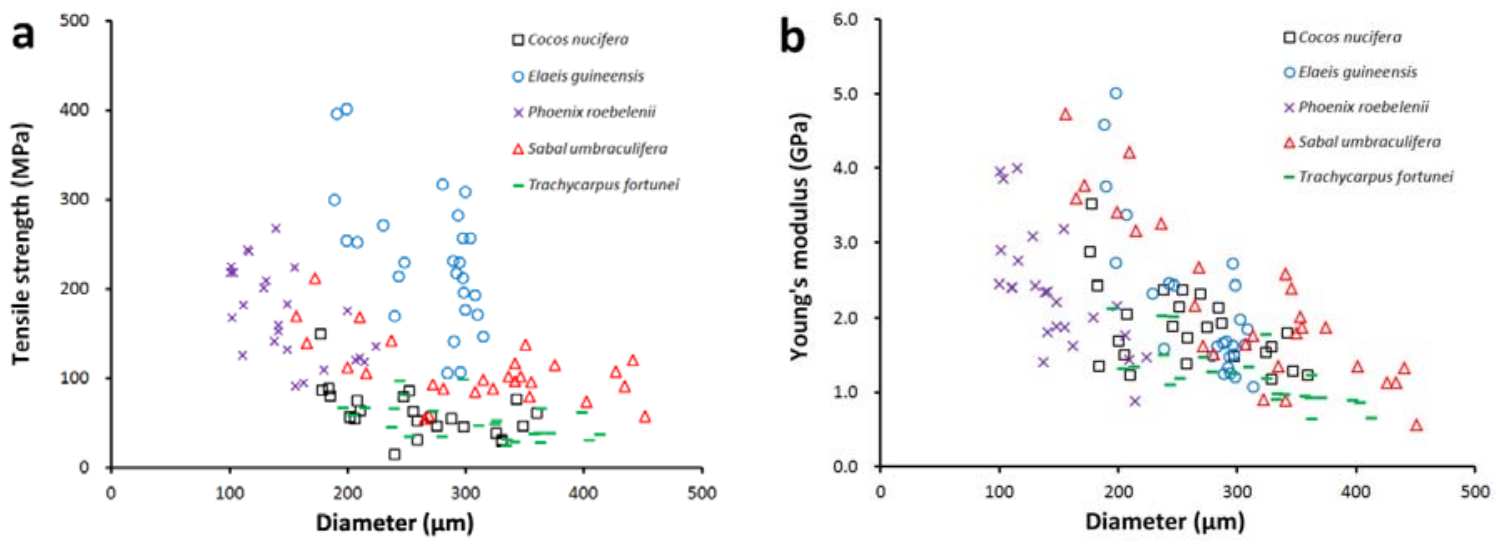

Fig. 5. Relationships between diameter and mechanical properties for the fiber bundles from five palm species. a- Tensile strength plotted as a function of diameter in palm fiber bundles. b- Young's modulus plotted as a function of diameter in palm fiber bundles. 
Table 1. Fiber dimensions* and the derived values among different palm species.

\begin{tabular}{|c|c|c|c|c|c|c|}
\hline Species & Fiber length (mm) & Fiber diameter $(\mu \mathrm{m})$ & Cell wall thickness $(\mu \mathrm{m})$ & Slenderness ratio & Flexibility coefficient & Runkel ratio \\
\hline Arenga engleri & $1.66( \pm 0.24)$ & $15.6( \pm 1.9)$ & $4.2( \pm 0.5)$ & 107.7 & 45.9 & 1.21 \\
\hline Arenga sp. & $1.85( \pm 0.20)$ & $13.8( \pm 1.6)$ & $4.2( \pm 0.9)$ & 136.3 & 39.5 & 1.72 \\
\hline Butia capitata & $1.53( \pm 0.28)$ & $11.7( \pm 1.8)$ & $3.2( \pm 0.5)$ & 132.8 & 45.0 & 1.28 \\
\hline Caryota maxima & $1.12( \pm 0.30)$ & $16.9( \pm 3.3)$ & $3.8( \pm 1.6)$ & 69.1 & 54.7 & 0.80 \\
\hline Caryota monostachya & $1.76( \pm 0.48)$ & $20.4( \pm 4.5)$ & $4.0( \pm 1.0)$ & 88.6 & 56.9 & 0.73 \\
\hline Caryota urens & $1.45( \pm 0.24)$ & $16.9( \pm 2.5)$ & $4.4( \pm 0.8)$ & 87.3 & 48.0 & 1.12 \\
\hline Cocos nucifera & $1.05( \pm 0.29)$ & $16.7( \pm 3.2)$ & $3.4( \pm 0.9)$ & 63.7 & 59.2 & 0.73 \\
\hline Corypha umbraculifera & $1.11( \pm 0.32)$ & $15.8( \pm 2.4)$ & $2.3( \pm 0.7)$ & 72.1 & 70.7 & 0.43 \\
\hline Elaeis guineensis & $0.95( \pm 0.26)$ & $15.1( \pm 1.9)$ & $3.2( \pm 0.5)$ & 63.8 & 58.7 & 0.72 \\
\hline Livistona chinensis & $0.76( \pm 0.14)$ & $15.5( \pm 1.7)$ & $2.1( \pm 0.4)$ & 49.7 & 72.3 & 0.39 \\
\hline Medemia nobilis & $0.92( \pm 0.28)$ & $13.5( \pm 1.7)$ & $2.5( \pm 0.5)$ & 69.7 & 63.1 & 0.62 \\
\hline Phoenix dactylifera & $1.28( \pm 0.29)$ & $17.0( \pm 3.3)$ & $4.0( \pm 0.7)$ & 77.9 & 52.4 & 0.96 \\
\hline Phoenix roebelenii & $0.66( \pm 0.18)$ & $11.6( \pm 1.5)$ & $2.2( \pm 0.4)$ & 57.9 & 61.2 & 0.66 \\
\hline Rhapis excelsa & $0.74( \pm 0.14)$ & $13.6( \pm 2.2)$ & $3.2( \pm 0.5)$ & 55.6 & 53.0 & 0.92 \\
\hline Sabal umbraculifera & $0.89( \pm 0.27)$ & $14.6( \pm 1.3)$ & $2.5( \pm 0.4)$ & 62.1 & 65.2 & 0.54 \\
\hline Syagrus romanzoffiana & $1.18( \pm 0.36)$ & $16.2( \pm 2.7)$ & $3.6( \pm 0.7)$ & 72.8 & 54.8 & 0.87 \\
\hline Trachycarpus fortunei & $0.67( \pm 0.13)$ & $13.4( \pm 2.4)$ & $2.2( \pm 0.9)$ & 50.9 & 66.1 & 0.56 \\
\hline Washingtonia filifera & $1.43( \pm 0.31)$ & $14.9( \pm 3.3)$ & $3.4( \pm 0.5)$ & 98.5 & 53.4 & 0.91 \\
\hline
\end{tabular}

*Data are represented as mean and \pm SD of 30 replications for each species. 
Table 2. Mechanical properties, MFAs and Klason lignin contents of fiber bundles from different palm species.

\begin{tabular}{|c|c|c|c|c|c|c|c|}
\hline Species & Diameter $(\mu \mathrm{m})$ & $\mathbf{S}_{\mathbf{V}} /\left(\mathbf{S}_{\mathbf{V}}+\mathbf{S}_{\mathrm{F}}\right)(\%)$ & Tensile strength (MPa) & Young's modulus (GPa) & BRK. Strain (\%) & $\operatorname{MFA}\left({ }^{\circ}\right)$ & Kalson lignin (\%) \\
\hline Arenga engleri & $259( \pm 57)$ & $7 \%$ & $202( \pm 78)$ & $2.9( \pm 1.7)$ & $13( \pm 8)$ & $10.3( \pm 1.4)$ & $29.6( \pm 3.2)$ \\
\hline Arenga sp. & $276( \pm 66)$ & $5 \%$ & $76( \pm 27)$ & $1.7( \pm 0.6)$ & $8( \pm 4)$ & $21.0( \pm 12.8)$ & $37.8( \pm 0.7)$ \\
\hline Butia capitata & $228( \pm 42)$ & $12 \%$ & $170( \pm 63)$ & $2.5( \pm 1.6)$ & $11( \pm 7)$ & $17.6( \pm 3.9)$ & $18.7( \pm 0.8)$ \\
\hline Caryota maxima & $202( \pm 65)$ & $5 \%$ & $128( \pm 48)$ & $2.3( \pm 1.5)$ & $40( \pm 25)$ & $30.1( \pm 3.3)$ & $38.2( \pm 0.3) * * *$ \\
\hline Caryota monostachya & $262( \pm 90)$ & $4 \%$ & $99( \pm 38)$ & $1.2( \pm 0.6)$ & $40( \pm 17)$ & $47.1( \pm 6.6)$ & $34.8( \pm 0.3)$ \\
\hline Caryota urens & $402( \pm 94)$ & $6 \%$ & $78( \pm 26)$ & $1.2( \pm 0.6)$ & $62( \pm 23)$ & $34.8( \pm 2.2)$ & $28.1( \pm 2.6)$ \\
\hline Cocos nucifera & $260( \pm 57)$ & $15 \%$ & $63( \pm 32)$ & $1.8( \pm 0.7)$ & $9( \pm 6)$ & $29.3( \pm 1.5)$ & $25.6( \pm 1.1)$ \\
\hline Corypha umbraculifera & $323( \pm 37)$ & $5 \%$ & $57( \pm 29)$ & $1.2( \pm 0.5)$ & $10( \pm 6)$ & $28.1( \pm 2.6)$ & $30.4( \pm 1.9)^{* * *}$ \\
\hline Elaeis guineensis & $269( \pm 42)$ & $25 \%$ & $228( \pm 74)$ & $2.2( \pm 1.1)$ & $17( \pm 5)$ & $21.1( \pm 13.1)$ & $26.2( \pm 2.0)$ \\
\hline Livistona chinensis & $250( \pm 63)$ & $30 \%$ & - & - & - & $24.2( \pm 2.6)$ & $31.6( \pm 0.8)$ \\
\hline Medemia nobilis & $236( \pm 60)$ & $8 \%$ & $83( \pm 31)$ & $1.7( \pm 0.7)$ & $24( \pm 12)$ & $29.7( \pm 3.5)$ & $34.7( \pm 2.2)^{* * *}$ \\
\hline Phoenix dactylifera & $473( \pm 125)$ & $10 \%$ & $147( \pm 76)$ & $1.5( \pm 1.0)$ & $25( \pm 15)$ & $15.6(-* *)$ & $18.3( \pm 1.3)$ \\
\hline Phoenix roebelenii & $147( \pm 39)$ & $3 \%$ & $162( \pm 52)$ & $2.1( \pm 0.9)$ & $21( \pm 8)$ & $23.5( \pm 1.4)$ & $33.0( \pm 0.3)^{* * *}$ \\
\hline Rhapis excelsa & $144( \pm 17)$ & $4 \%$ & $109( \pm 36)$ & $2.9( \pm 0.9)$ & $11( \pm 4)$ & $29.5( \pm 4.2)$ & $33.9( \pm 1.0)$ \\
\hline Sabal umbraculifera & $308( \pm 87)$ & $27 \%$ & $111( \pm 36)$ & $2.3( \pm 1.3)$ & $13( \pm 8)$ & $20.7( \pm 5.9)$ & $25.8( \pm 0.7)$ \\
\hline Syagrus romanzoffiana & $466( \pm 79)$ & $12 \%$ & $134( \pm 39)$ & $1.3( \pm 0.8)$ & $25( \pm 16)$ & $13.4( \pm 1.8)$ & $33.0( \pm 0.6)$ \\
\hline Trachycarpus fortunei & $307( \pm 65)$ & $12 \%$ & $54( \pm 23)$ & $1.2( \pm 0.5)$ & $12( \pm 8)$ & $38.9( \pm 4.5)$ & $35.9( \pm 1.2)$ \\
\hline Washingtonia filifera & $214( \pm 38)$ & $9 \%$ & $170( \pm 58)$ & $1.7( \pm 0.7)$ & $21( \pm 7)$ & $22.9( \pm 3.5)$ & $35.2( \pm 0.9)$ \\
\hline
\end{tabular}

* Data of mechanical properties are represented as mean and \pm SD of 30 replications for each species.

** Only one fiber bundle was tested for getting mean MFA. The measurements were performed in triplicate for other species.

*** The Klason lignin contents of these palm species include ash contents. These data were not used for discussion. 